\title{
Implementation of Lecture Scheduling Using Method - Auto Generate Timetable
}

\author{
Hani DewiAriestanti ${ }^{1}$, Ignatius Joko Dewanto ${ }^{2}$, DwiSloriaSuharti ${ }^{3}$, Muhamad Yusup ${ }^{4}$ \\ * Sistem Komputer, Teknik Informatika, STMIK Raharja \\ Jl. Jenderal Sudirman No. 40 Modern Cikokol Tangerang, Provinsi Banten Indonesia 15117 \\ ${ }^{1}$ hani.dewi@raharja.info \\ 2joko.dewanto@raharja.info \\ ${ }^{4}$ yusup@raharja.ac.id \\ *Universitas Muhammadiyah Tangerang \\ Jl. Perintis Kemerdekaan I No. 33 Cikokol, Babakan Kec. Tangerang Banten 15118 \\ ${ }^{3}$ dwisloria@umt.ac.id
}

\begin{abstract}
The purpose of this research is to produce Lecture Scheduling Using the Auto Generate Timetable Method that can be used effectively for lectures at Raharja Higher Education. The research problem in arranging schedule in the college are time, space and timeslots. Considering the list of hard constraints and soft constraints presented in one semester, thus no conflicts are created in allocating the schedule. Research methods used are questionnaires and fixed study cards, as well as System Development Life Cycle (SDLC) methodology and Object Oriented Analyses Design (OOAD). The tools used are UML, Xamp with Apache software support, PHP, MySql, and Yii Framework. The final result of this research is the application of scheduling arrangement and fixed study card which can be used for lectures at the scope of Raharja College to support academic administration system in the scope of Higher Education. Follow-up of this research is to develop academic information system.
\end{abstract}

Index Terms - Lecture Scheduling, Auto Generate Time Table, SDLC, OOAD, Xamp

\section{INTRODUCTION}

One of the most important components of academic information systems is scheduling lectures. In college, scheduling program is one of the important things in the teaching and learning process, because all lecturer and student activities are dependent on the schedule, so it must be properly arranged and improved at the beginning of the academic year, so that it will not interfere with teaching and learning activities among lecturers and student (Ariani, Fahriza, et. al, 2011). Artificial intelligence, or AI, is the field that studies the synthesis and analysis of computational agents that act intelligently (Poole and David, et. Al., 2010). Lecturing scheduling problems include lecturers and spaces that can clash at the same time, availability of teaching time for lecturers is not fixed, space limitations, even distribution of courses in every week.Besides the obstacles that occur is on the preparation of lecture scheduling problems in terms of students, the limited number of lecturers to teach college. In addition, the availability of classes to learning activities undertaken which is the problem above is usually known as University Timetabling Problem (UTP).

Based on the aspects that have been discussed above, then it is needed the process of lecture scheduling which is not too much or it minimizes the constraints. Thus, it requires optimization that can be applied in making the lecture scheduling. This optimization cannot fully produce optimal results but it is near optimal. There are several optimization methods that are often used to accomplish the scheduling which each has its own advantages (Azis, 2015). These methods include Ant Colony, Simulated Annealing, Genetic Algorithm. And the advantage of Ant Colony is perfectly applicable with minimal change to the combination optimization problem. Simulated Annealing has the advantage that is faster in solving iteration while Genetic Algorithm can be used to find various solution problem that exist in real world.

Furthermore, several previous studies have made comparisons between the Genetic Algorithm and the Palgunadi Algorithm for the course scheduling (Yudihartanti, Syukur, et.al., 2015). This study has resulted in a combination of genetic algorithms and palgunadi algorithms with the resulting heuristic process improvement of the Genetic Algorithm evidenced by the improved fitness value generated and the less process time required (Siswono, 2013). In addition, Yudihartanti has analyzed the Comparative Method of Mamdani and Sugeno Method in the scheduling of subjects where there are differences in the process done eg in the process of aggregation implication and defuzzification process. In the trial process with the dataset obtained that the comparative results show that Mamdani method has a higher level of accuracy than the Sugeno method (Yudihartanti et al., 2011).

In designing this lecture scheduling, the problem on timetable is quite wide. According to Gani (2004), timetable is the allocation of subject that has constraints to be placed on time space. This problem exists in daily 
life, education, health, transportation, sports and production companies (Chu and Chen, 2006). The optimal timetable completion process is quite complicated and time consuming if completed manually (Norberciak, 2008), according to him there are several methods of time table completion and scheduling, namely: sequential method, cluster method, constraint based method and meta heuristic method.

The method taken in this research is the constraint method, by type, there are 2 types of constraints, namely the constraint that is tough (hard constraints) and the constraint is weak (soft constraint) (Montero, 2011). Obstacles that are tough must be met, so there should be no violation of this obstacle. While the weak constraints do not have to be met. These more complicated constraints are resolved than those that are assertive. The problems of these constraints are various from institution to another institution, but mostly it is similar that is time constraints (Islam, Shahriar, et.al, 2016).

In the allocation of time, each scheduled task unit must be allocated some number of work units, such as person-days of effort. And each task must be assigned a start date and a completion date that are a function of the interdependencies and whether work will be conducted on a full-time or part-time basis (Pressman, 2010).

A scheduling issue that links the worker's personal preference to the availability of working hours within the organization is discussed in proposing that each of these personal desires be used as a sought-after solution at the last stage when the schedule is verified by the team within the organization. The concept is offered in Gunawan and Toba (2016). They created separate modules between the initial timetable generation, undercover and overstaffing in the shift of working hours, and then verifying the personal desires of the workers. It is considered appropriate to be done in the context of a workers' schedule in the organization in the number of workers quite a lot because it can allocate schedules to other workers. Automated Timetables: A lot of efforts have been made by many researchers to design a software that can produce the timetable automatically (Kumar and Sharma, et.al, 2012).

However, Array as the simplest data structure can be one-dimensional or so-called array, and can also be two-dimensional or so-called matrix. The matrix is a two-dimensional array. An array is a data connection of the same type, arranged in the form of a sequential current and the number of elements or data does not change according to the initial declaration. Under convention, the first index is a row, the second index is a column (Putri, 2014).

Furthermore, Object Oriented Design (OOD) describes all object types of objects needed to be able to communicate with people and devices present in the system. Describing how objects can accomplish tasks, and customizing and perfecting each type object. Thus, it can be implemented with a specific language or environment (Satzinger and Jackson, et.al 2014).

From these problems, we need a method that can solve timetable quickly and precisely. Therefore, lecture scheduling is proposed using Auto Generate Timetable with Array, is an optimization method used for scheduling lectures to solve multidimensional optimization problems with faster processing time.

The purpose of this research is to: a) Design application Lecture scheduling using Auto Generate Timetable with Array method, b) Provide application of lecture scheduling system which is made more flexible according to the type of constraints and parameters that exist in each university or college. Later, this application can be applied in a wider scope.

The urgency of this research is that the lecture scheduling system plays an important role in educational and learning activities to assist the process of arranging the schedule of lectures to be easier, more effective and efficient in the process of determining lecture scheduling by considering the list of hard constraints and soft constraints presented in one semester. Subsequently, there is no conflict which is occured in allotting the schedule.

This application is built with a framework, which contains function and class that use MVC method. MVC is a method that separates parts of a web application consisting of model, view, and controller. One of the web framework is Yii framework, with Yii framework of making and developing web-based application is expected to be faster and easier both for development and maintenance. This research will produce a lecture scheduling application by applying Auto Generate Timetable method with Array as its optimization method.Concerning the differentiating factors with other lecture scheduling applications is in the application of lecture scheduling which will be developed. It is made web-based with Yii Framework. In addition, It is being made more flexible in accordance with the type of constraints and parameters that exist in each university or college. Therefore, this application can be applied in a wider scope.

\section{Procedure for Paper Submission}

The research method used to build the application of lecture scheduling with Auto Generate Timetable method with Array includes field observation both head of study program and students, SDLC (System Development Life Cycle) method, Object Oriented Analyses Design (OOAD) and user interface. Formulation of research for development of lecture scheduling using Auto Generate Timetable method with Array, using the following fishbone diagram method: 


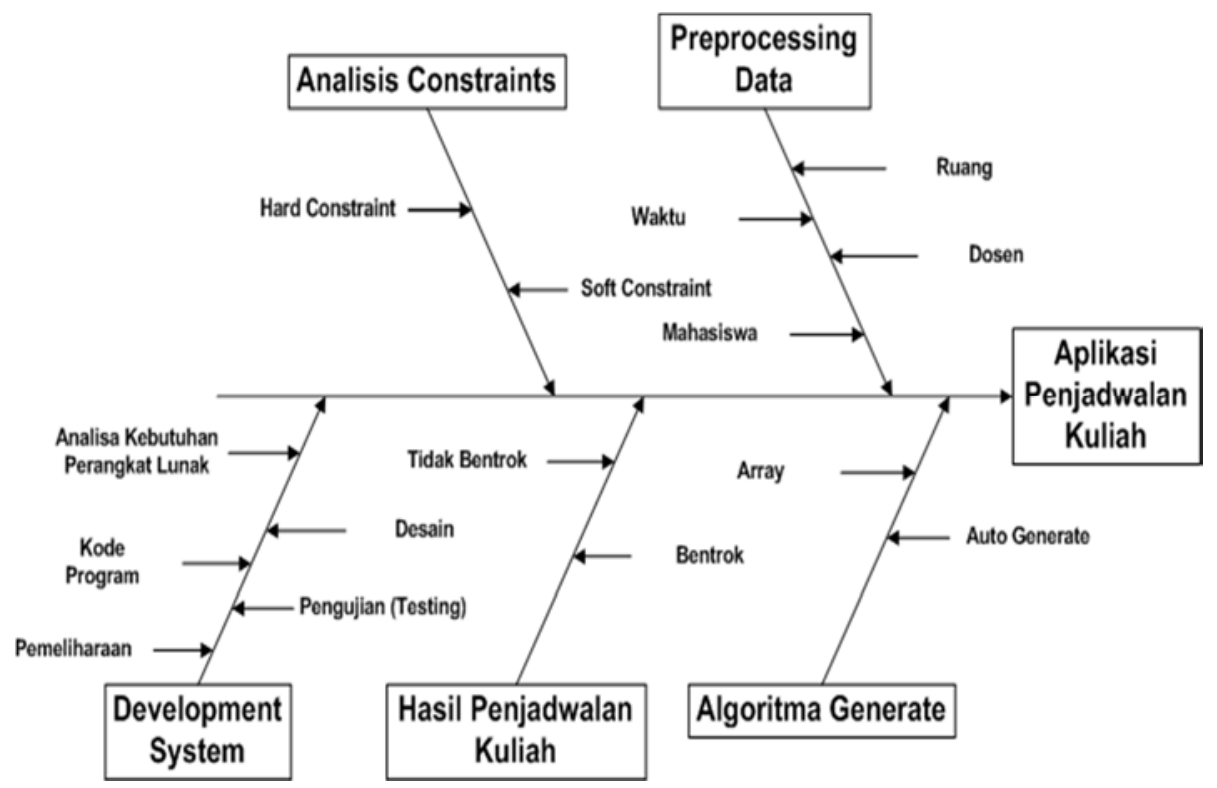

Fig.1. Fisfbone of Research Diagram

\section{A. System Development}

OOAD design on scheduling system by making use case diagram. And activity diagram of running system and class diagram as follows:

\section{Use Case Diagram Schedule System}

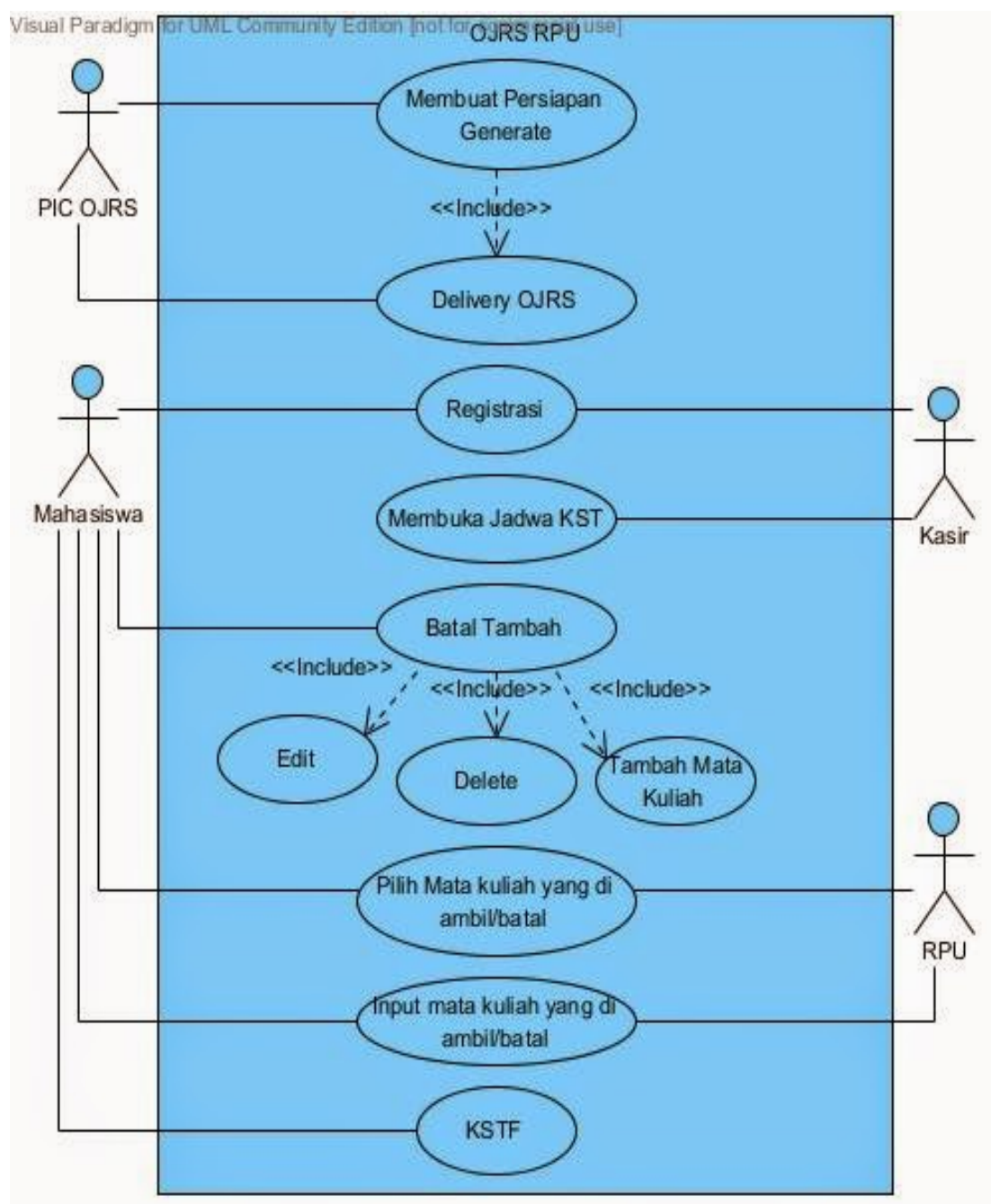

Fig.2. Use Case Sistem Schedule 
PIC Online Study Schedule Schedule (OJRS) prepared Generate, then data generated to OJRS and the schedule was ready for student registration in determining the fixed study card, KartuStudiTetap (KST). The student also allowed to make improvements, that was to delete and add the course. Furthermore, RPU chosed the course which was taken and voided to add students. Finally, the student determined the final fixed study card, KartuStudiTetap Final - (KSTF).

\section{Activity Diagram Schedule System}

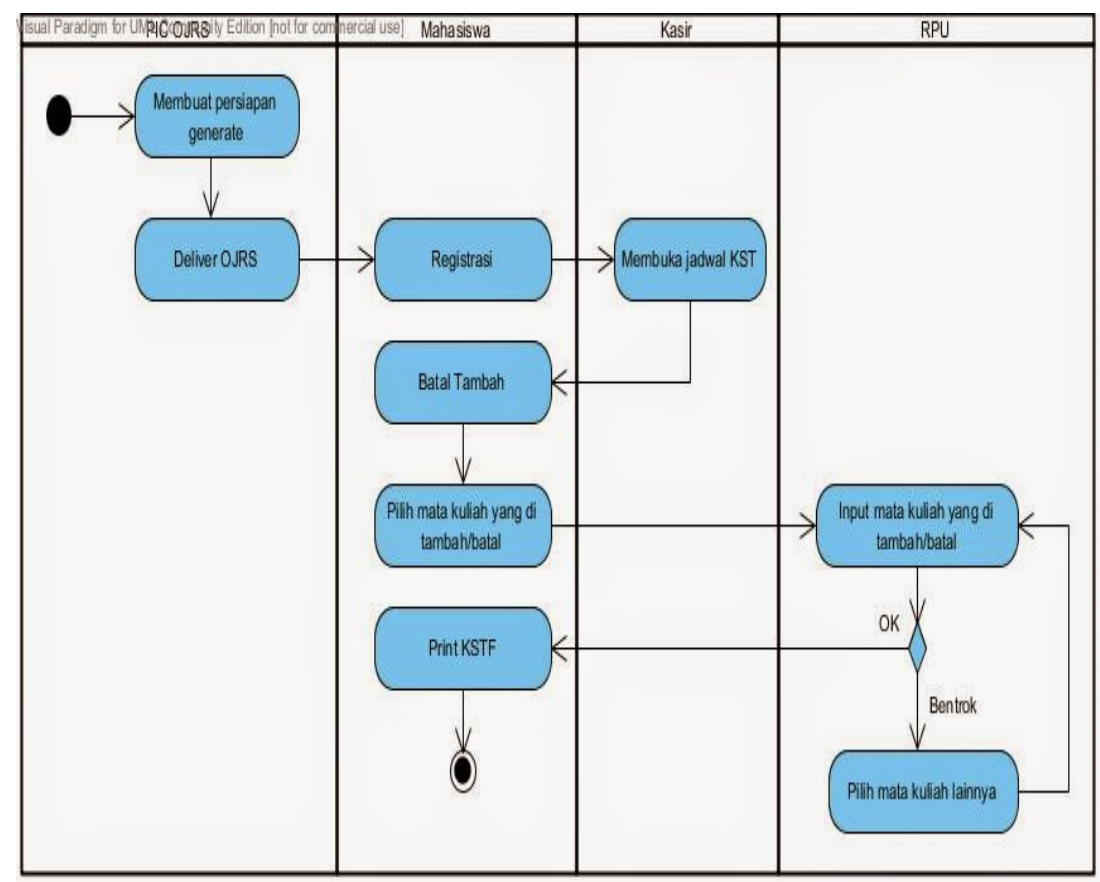

Fig.3.Activity Diagram Schedule

\section{Class Diagram Schedule Systems}

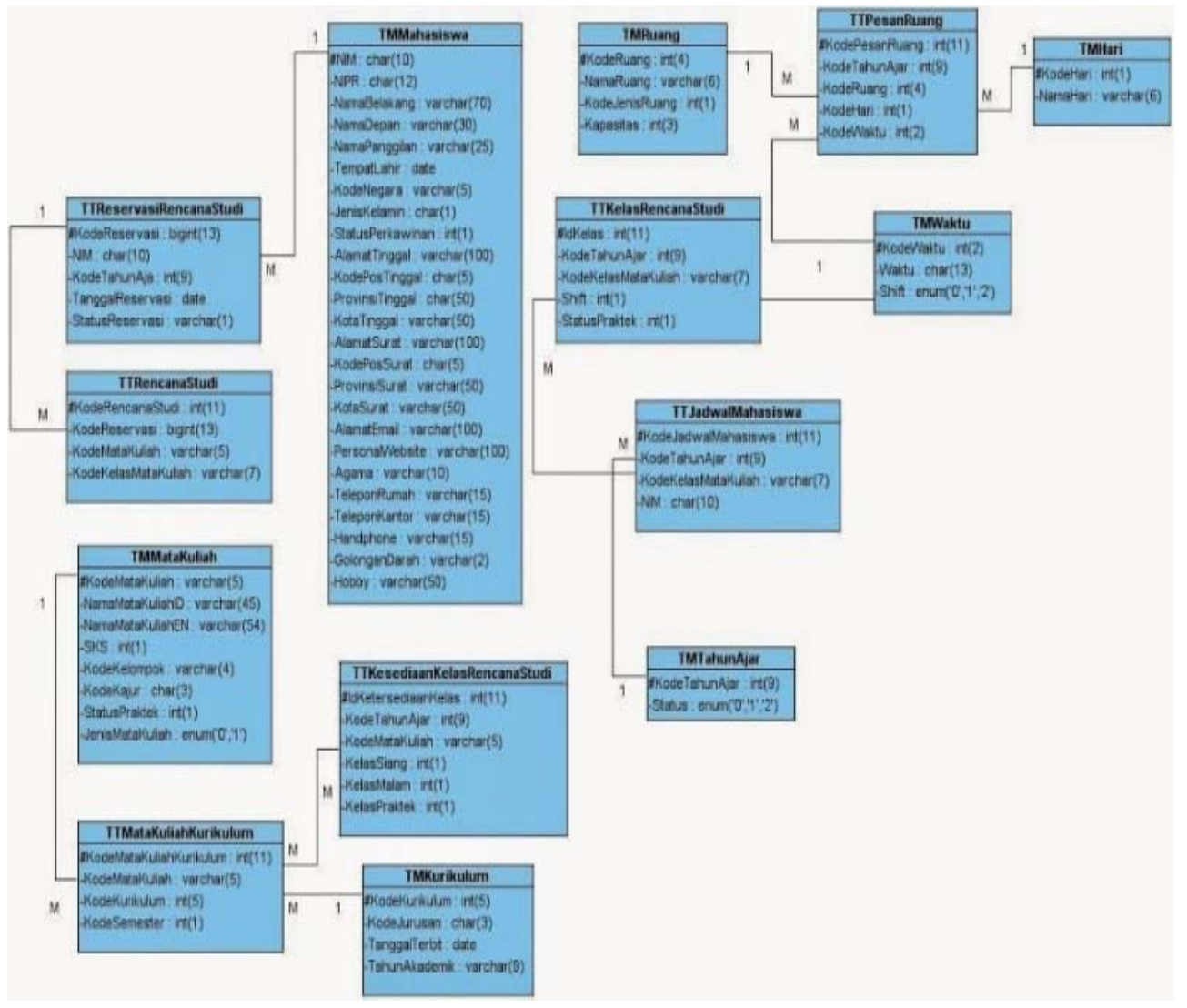

Fig.4.Class Diagram Schedule Systems 


\section{Taken from: https://widuri.raharja.info/index.php/SI1022465187}

\section{B. User Interface Prototype}

Interface design for scheduling system requirements

1. Soft Constraints Lecture Timeslots Form Design

\begin{tabular}{|c|c|c|c|c|c|}
\hline SENIN [jam Ke] & SELASA [jam Ke] & RABU [Jam Ke] & KAMIS [lam Ke] & JUMAT [Jam Ke] & SABTU [lam Ke] \\
\hline $008: 00 \cdot 08: 50[1]$ & $08: 00 \cdot 08: 50[1]$ & $08: 00 \cdot 08: 50[1]$ & $08: 00 \cdot 08: 50[1]$ & $08: 00 \cdot 08: 50[1]$ & $08: 00 \cdot 08: 50[1]$ \\
\hline $08: 50 \cdot 09: 40[2]$ & $08: 50 \cdot 09: 40[2]$ & $08: 50 \cdot 09: 40[2]$ & $008: 50 \cdot 09: 40[2]$ & $08: 50 \cdot 09: 40[2]$ & $08: 50 \cdot 09: 40[2]$ \\
\hline $09: 40 \cdot 10: 30[3]$ & $09: 40 \cdot 10: 30[3]$ & $09: 40 \cdot 10: 30[3]$ & $09: 40$ - 10:30 [3] & $09: 40 \cdot 10: 30[3]$ & $09: 40 \cdot 10: 30[3]$ \\
\hline ㅁ 10:30-11:20[4] & $10: 30 \cdot 11: 20[4]$ & D 10:30-11:20[4] & D 10:30 - 11:20[4] & [10:30-11:20[4] & [10:30-11:20[4] \\
\hline 11:20-12:10[5] & D 11:20-12:10[5] & 11:20-12:10[5] & 11:20-12:10[5] & $11: 20 \cdot 12: 10[5]$ & Q11:20-12:10[5] \\
\hline [12:10.13:00[6] & {$[12: 10 \cdot 13: 00[6]$} & [12:10-13:00[6] & $12: 10 \cdot 13: 00[6]$ & [12:10-13:00 [6] & $12: 10 \cdot 13: 00[6]$ \\
\hline D 13:00-13:50[7] & D 13:00-13:50[7] & [13:00-13:50[7] & $013: 00-13: 50[7]$ & (13:00-13:50[7] & $013: 00 \cdot 13: 50[7]$ \\
\hline (13:50 - 14:40 [8] & $13: 50-14: 40[8]$ & $13: 50-14: 40[8]$ & $13: 50-14: 40[8]$ & $13: 50-14: 40[8]$ & $13: 50-14: 40[8]$ \\
\hline 14:40 - 15:30 [9] & 14:40 - 15:30[9] & 18:40 - 15:30[9] & 14:40 - 15:30[9] & D 14:40 - 15:30 [9] & $14: 40 \cdot 15: 30[9]$ \\
\hline [D $15: 30 \cdot 16: 20[10]$ & D 15:30-16:20[10] & [15:30-16:20[10] & $15: 30 \cdot 16: 20[10]$ & Q 15:30-16:20[10] & [15:30-16:20[10] \\
\hline [16:20-17:10[11] & Q16:20.17:10[11] & $16: 20 \cdot 17: 10[11]$ & [16:20-17:10[11] & 16:20-17:10[11] & Q16:20-17:10[11] \\
\hline [17:10-18:00[12] & ㅂ. 17:10-18:00 [12] & D 17:10 - 18:00[12] & 17:10 - 18:00[12] & [17:10-18:00 [12] & $17: 10 \cdot 18: 00[12]$ \\
\hline $18: 30 \cdot 19: 20[13]$ & D 18:30-19:20[13] & (18:30-19:20 [13] & D 18:30-19:20 [13] & D $18: 30 \cdot 19: 20[13]$ & D 18:30-19:20[13] \\
\hline (19:20-20:10[14] & $19: 20 \cdot 20: 10[14]$ & (19:20-20:10[14] & D 19:20-20:10[14] & $19: 20 \cdot 20: 10[14]$ & D $19: 20 \cdot 20: 10[14]$ \\
\hline $20: 10 \cdot 21: 00[15]$ & $20: 10 \cdot 21: 00[15]$ & $20: 10 \cdot 21: 00[15]$ & $20: 10 \cdot 21: 00[15]$ & $20: 10 \cdot 21: 00[15]$ & $20: 10 \cdot 21: 00[15]$ \\
\hline DAll & DAll & Gall & DAll & DAll & $\square$ All \\
\hline
\end{tabular}

Fig.5. Soft Constraints Interface Lecture Timeslots

The design of the lecture class with the identification of 15 slots that will be prepared as a lecture schedule

2. Result of Generate Use of Classrooms Against Time Form Design

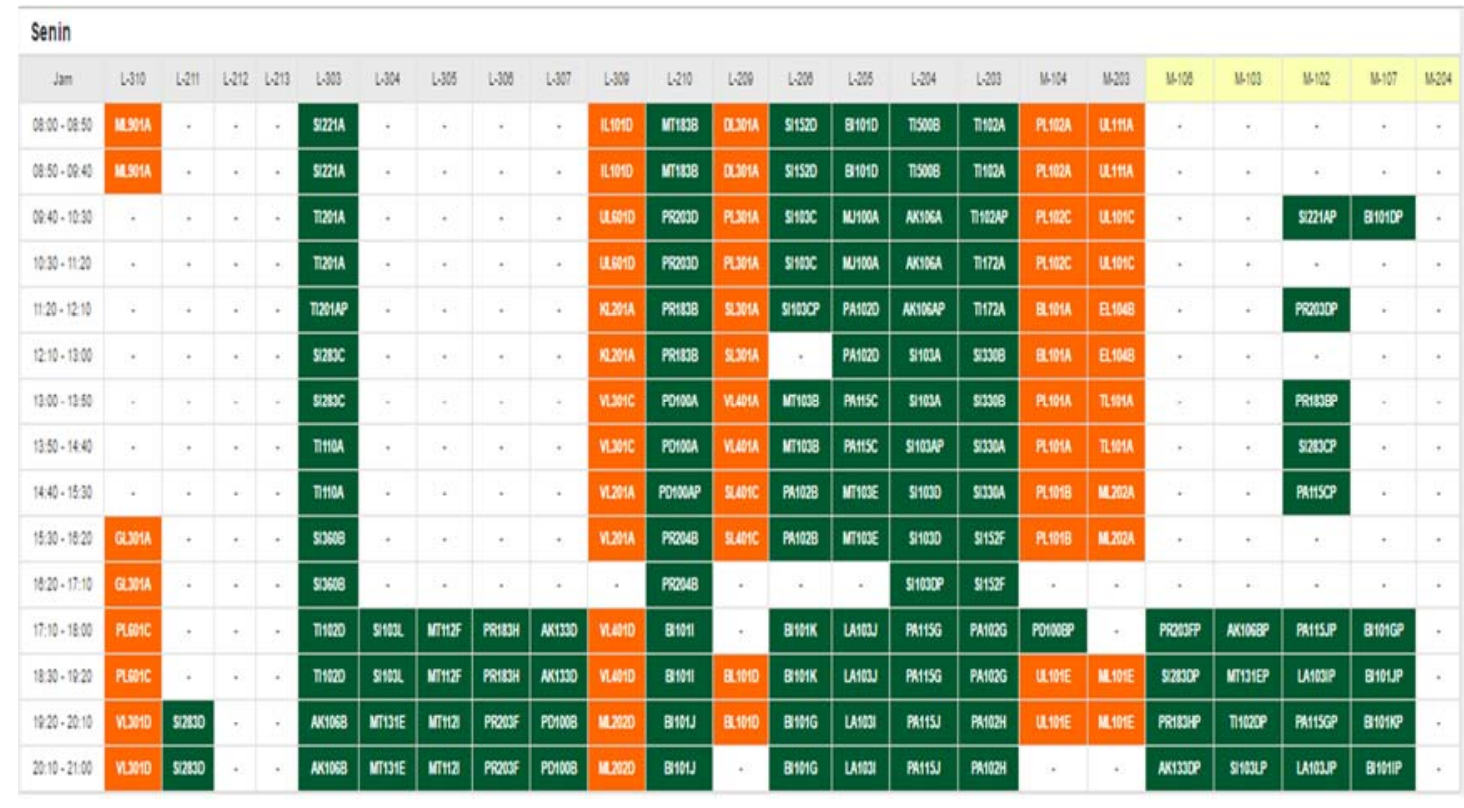




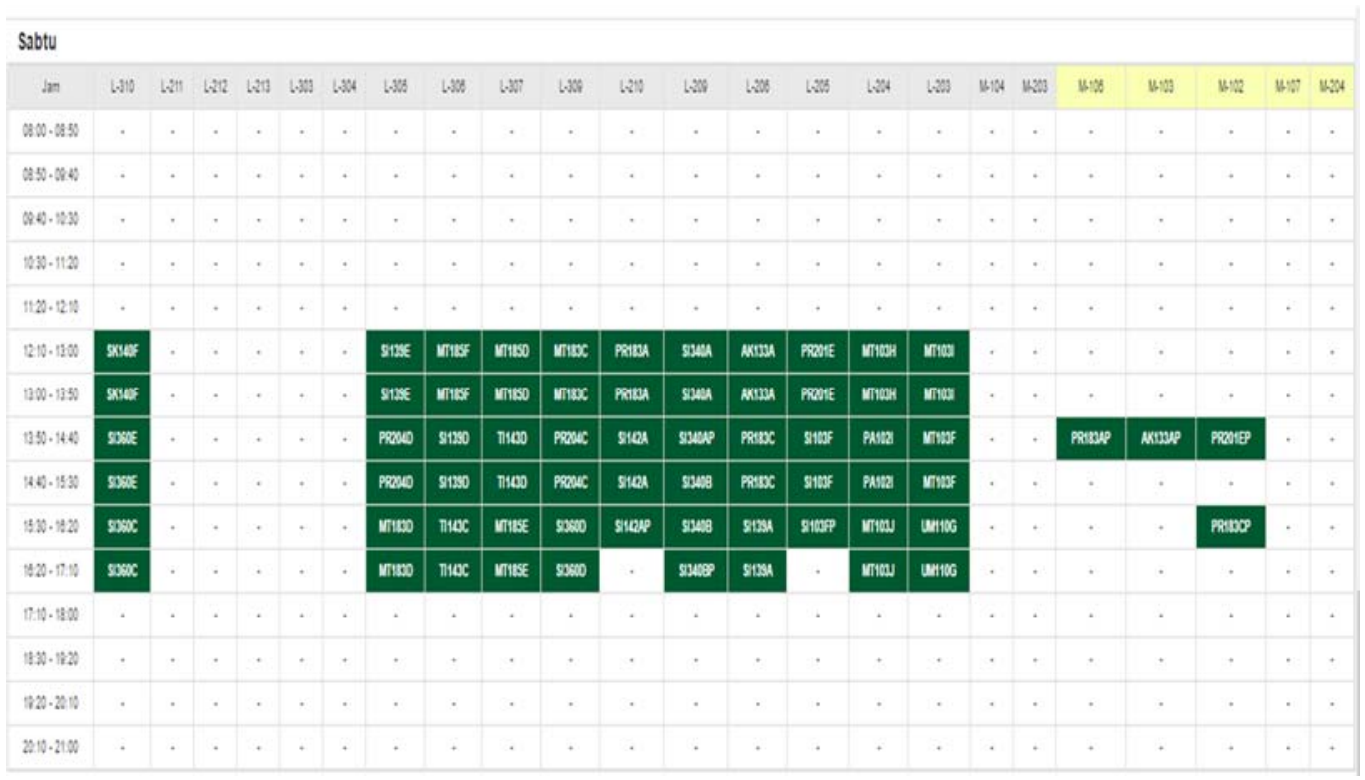

Fig.6.Interface Results Generate (Generation) Use of Classroom Time (Timeslot)

The Form Design of Generate Result (Generation) Use of Classroom Against Time (Timeslot)

\section{Analysis and Discussion}

\section{Analysis Constraints}

The existing schedule of jadwalperkuliahan or existing lectures was conducted by the survey and analyzed the schedule of the lectures

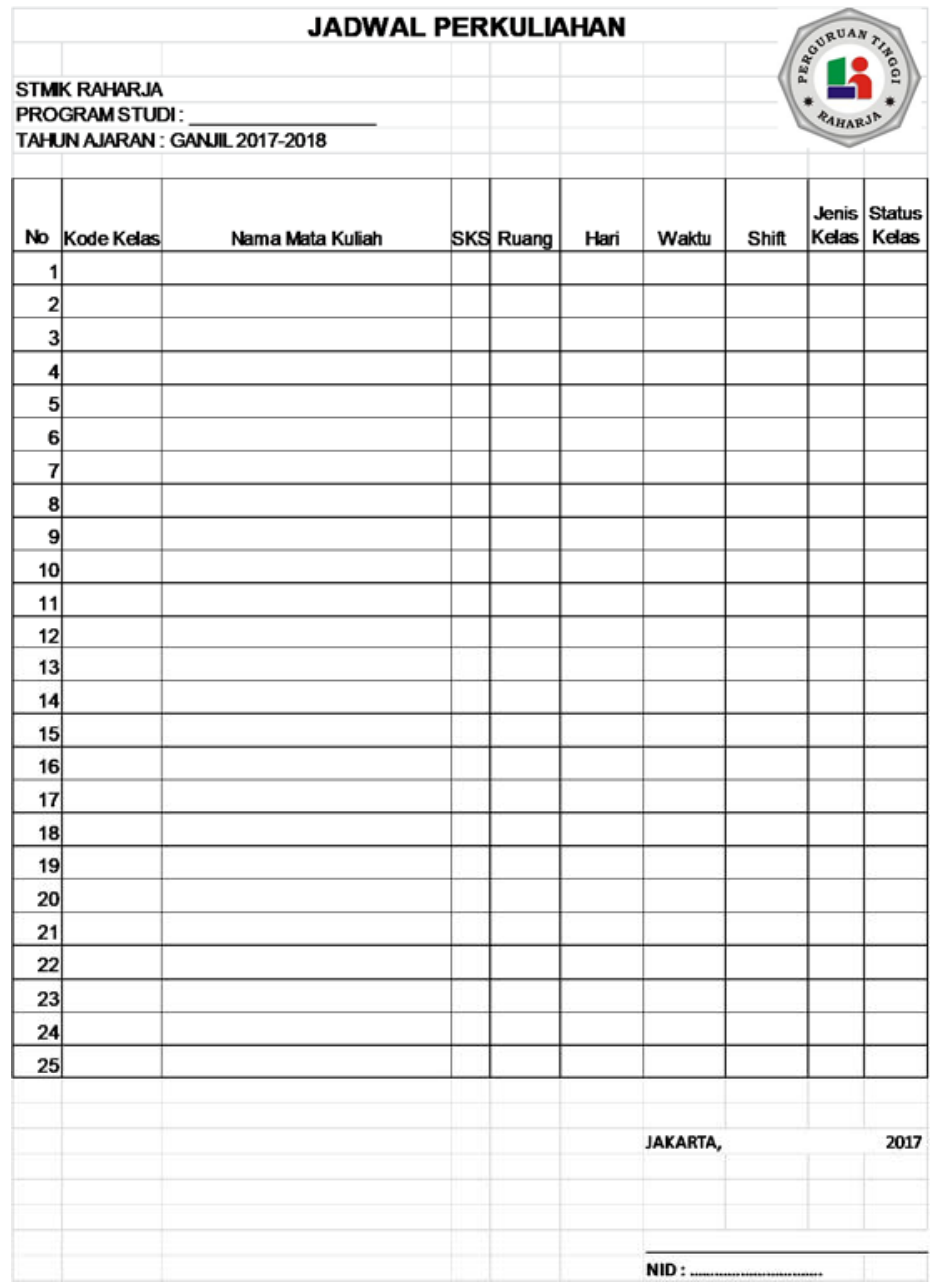

Fig.7. Schedule Courses 


\section{Analysis of Study Card Fixed}

The desirability of the pulldown menu on the registered number of student, NomorIndukMahasiswa (NIM) and Name entry is together with the level of study, majors, concentration, shift, credit (SKS), day, space, and time. It is done to fill the data as usual.

2. Analysis of Schedule

Completion of lecture scheduling system began with entering SKS data, Space, payment (SPP), KRS arrangement, and lecture scheduling: classroom (space), schedule courses, and class code. Then, it was strongly agreeing that this indicated good class: class code, course, sks, space, day, shift, class type, class status, class quota.

Some notes given by the head of department were:

- High queue alterations occurred high queue. It built up at the time of user built up resulted a high loading, hangs and even system crashes

- Generate treatment that had been implemented should not be done to add cancel process

- The current scheduling of 15 slots changed into 17 slots

In the implementation of scheduling system there were several implementation of the work, among others:

1. Login to SIS +

Regarding to run the online lecture system, STMIK Raharja used iLearning Services + in system that could process the academic system in the scope of lectures for students in scheduling, lecturing and lecturing courses.

\section{STUDENTS iLEARNING SERVICES ${ }^{+}$}

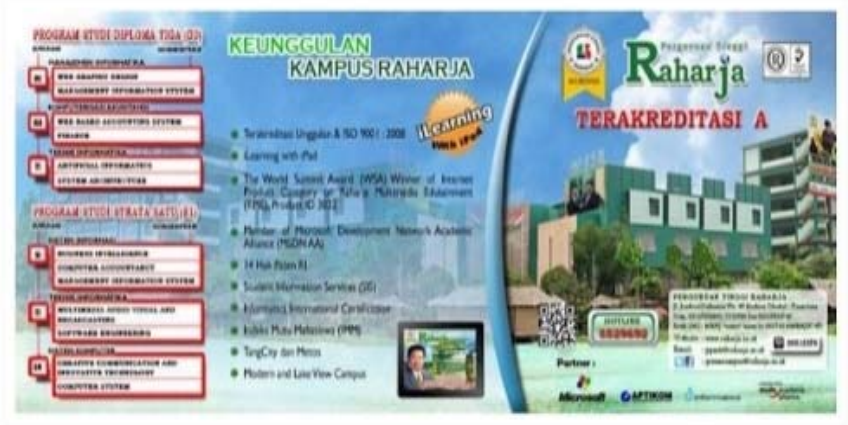

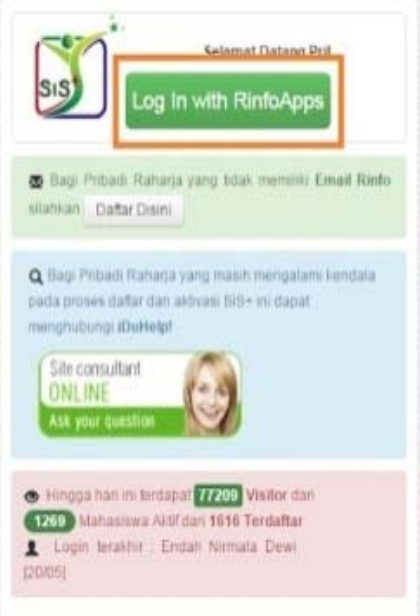

Fig.8.Login SIS+

2. Create Tiket OJRS +

Create ticket is a facility used to create OJRS + ticket by logging in using email which is registered on via gmailRinfo, which is an email identification of employee and lecturer of Perguruan Tinggi Raharja, Raharja college.

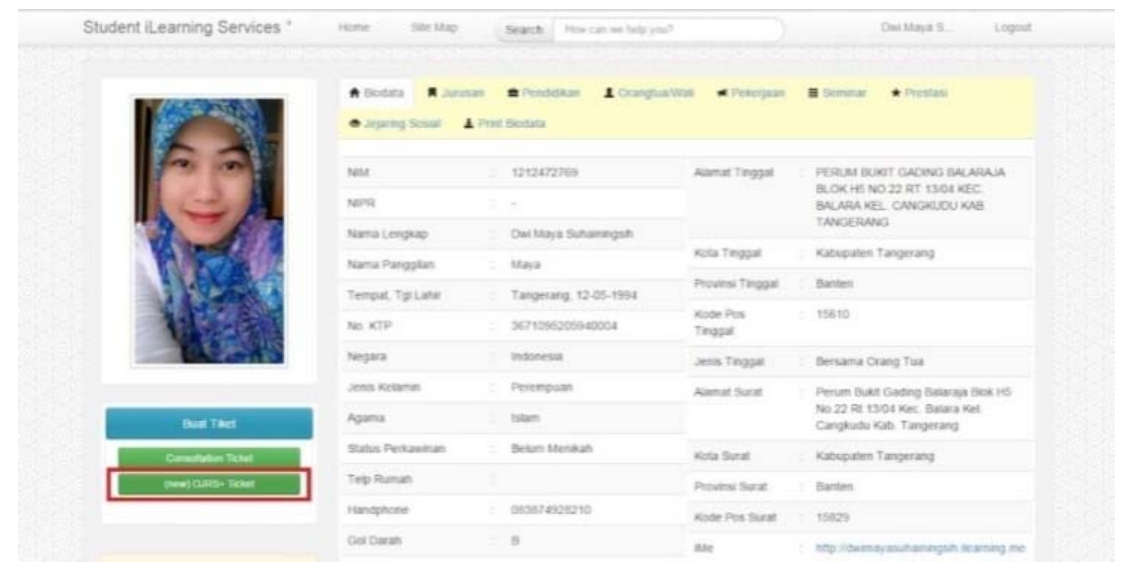

Fig.9.Create Ticket OJRS+ 
3. Make of Code Tiket OJRS+

Conduct an existing ticket booking on OJRS + which can be used to cancel or/and add (bataltambah) OJRS +

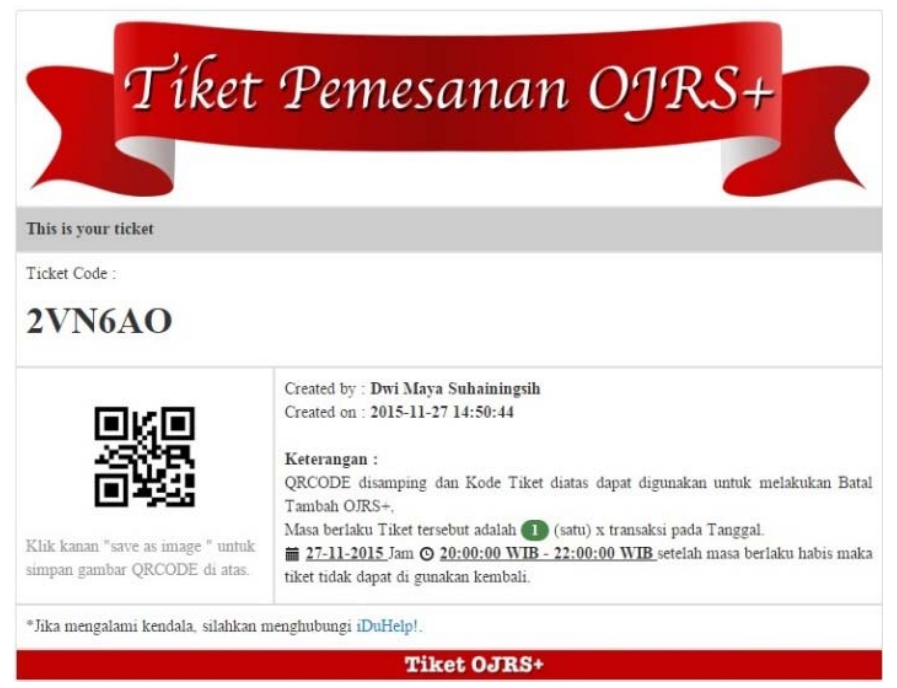

Fig.10.Order Ticket OJRS+

4. Keyword OJRS+

Keyword OJRS + Login using Single Sign On (SSO) identified through gmailRinfo, which is the email identification of employees and lecturers' Raharja college.

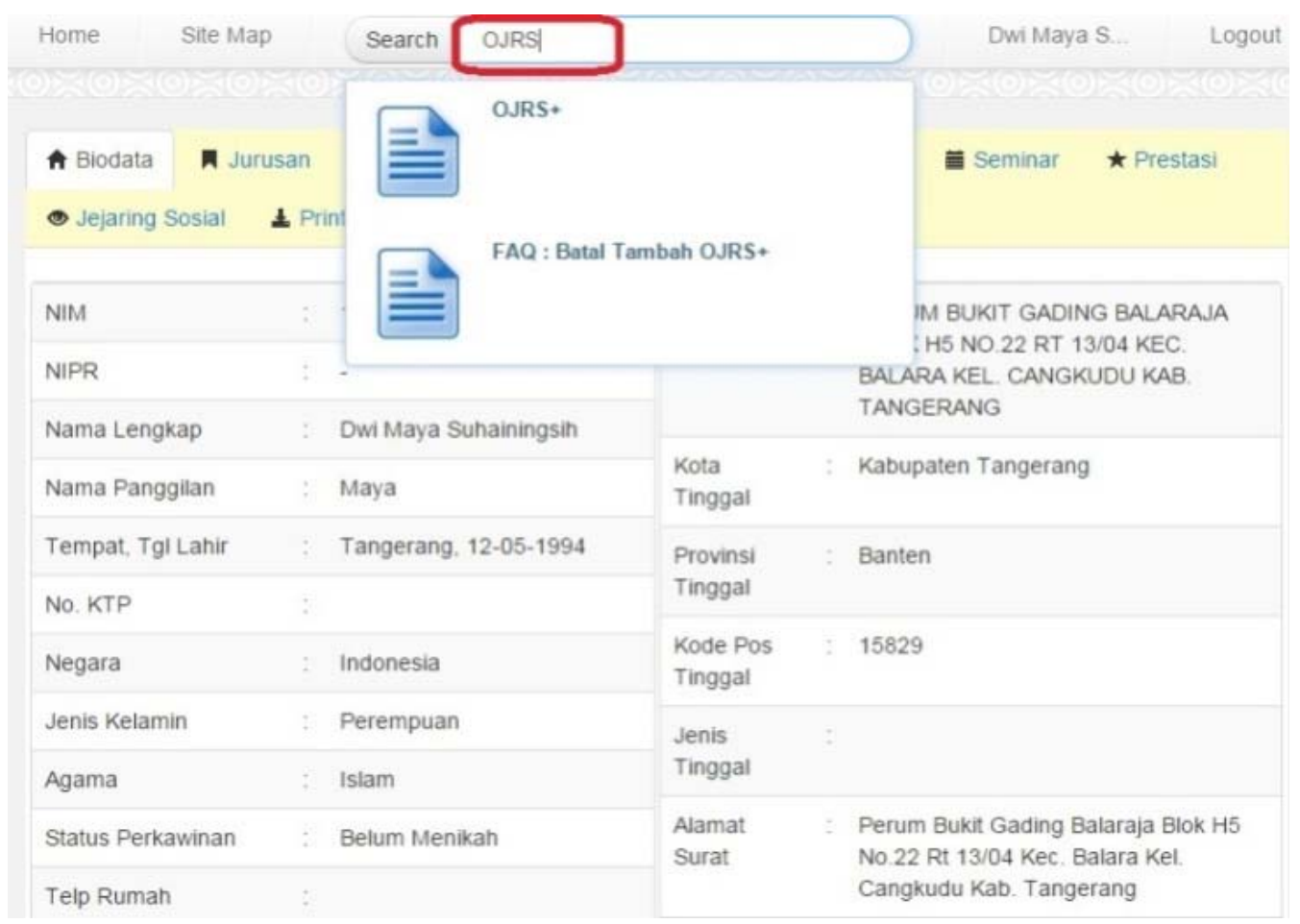

Fig.11.Keyword OJRS+

5. Cancel Add Form

Cancel Add Form is a facility used by the students after the study program conducted the scheduling of lectures whose data is used to make the invalid added the lecture data which is to be taken. 


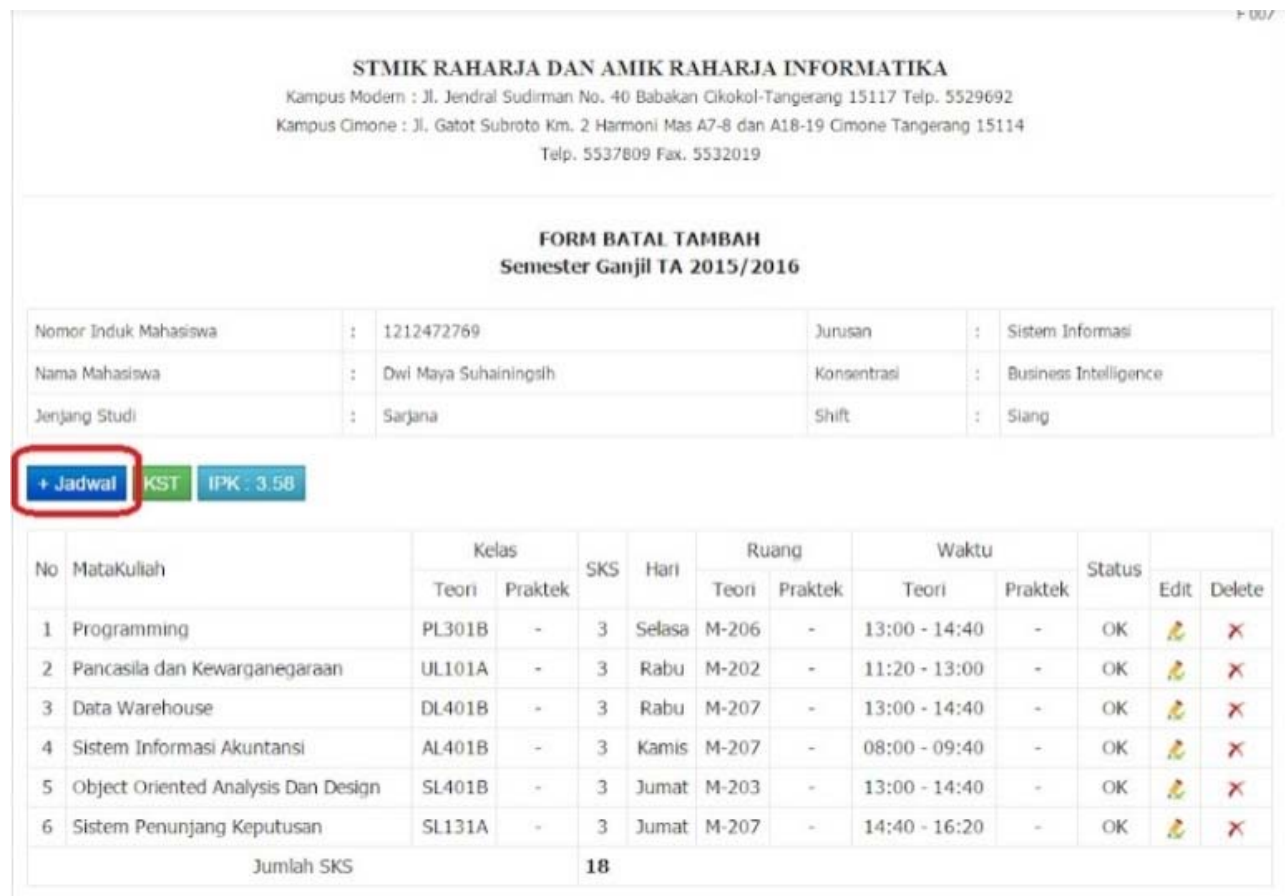

\section{Fig.12.Cancel Add Form}

\section{Added Course Form}

The Added Course Form is an added course for each student who will add a course that will run for one semester.

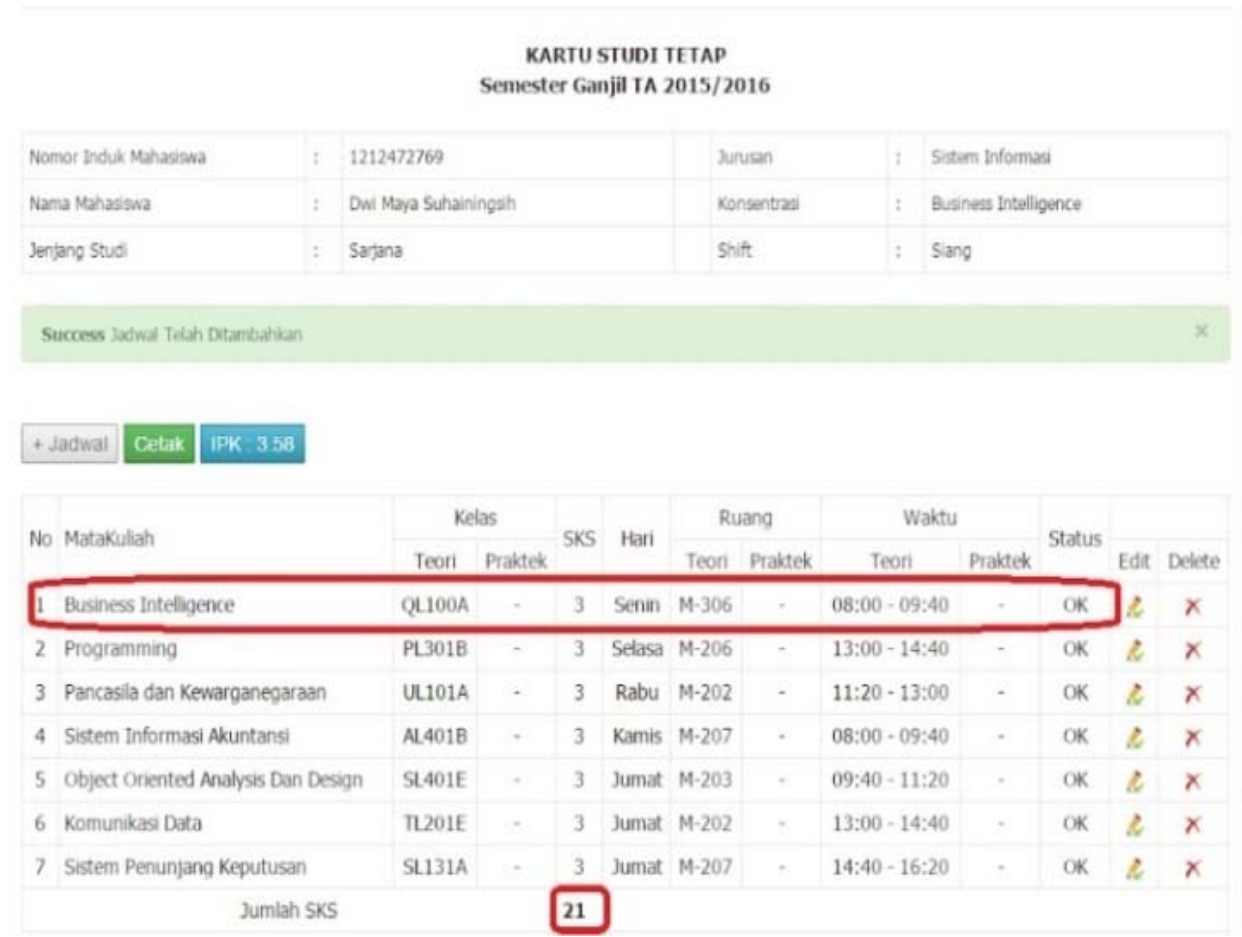

Fig.13.Permanent Study Form

\section{KST Form}

The Fixed Study Card Form (KST) is a fixed study card which still allows to make the Add Cancel Form. This section is a preparation form to get to KSTF 


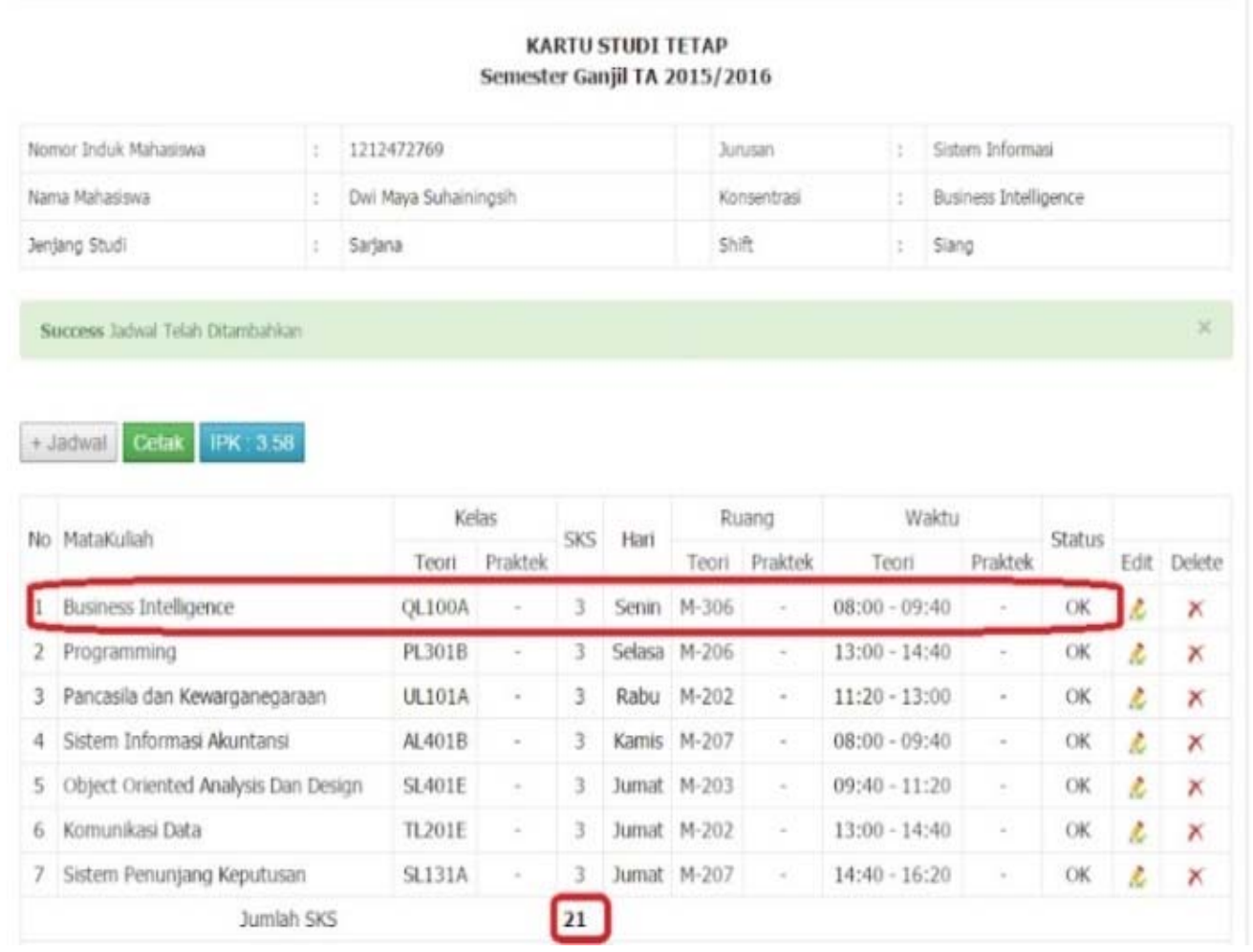

Fig.14.Form KST

\section{KSTF Form}

The Final Study Card Form (KSTF) is a final fixed study card that has not been subjected to a change of the course that will be executed for one semester.

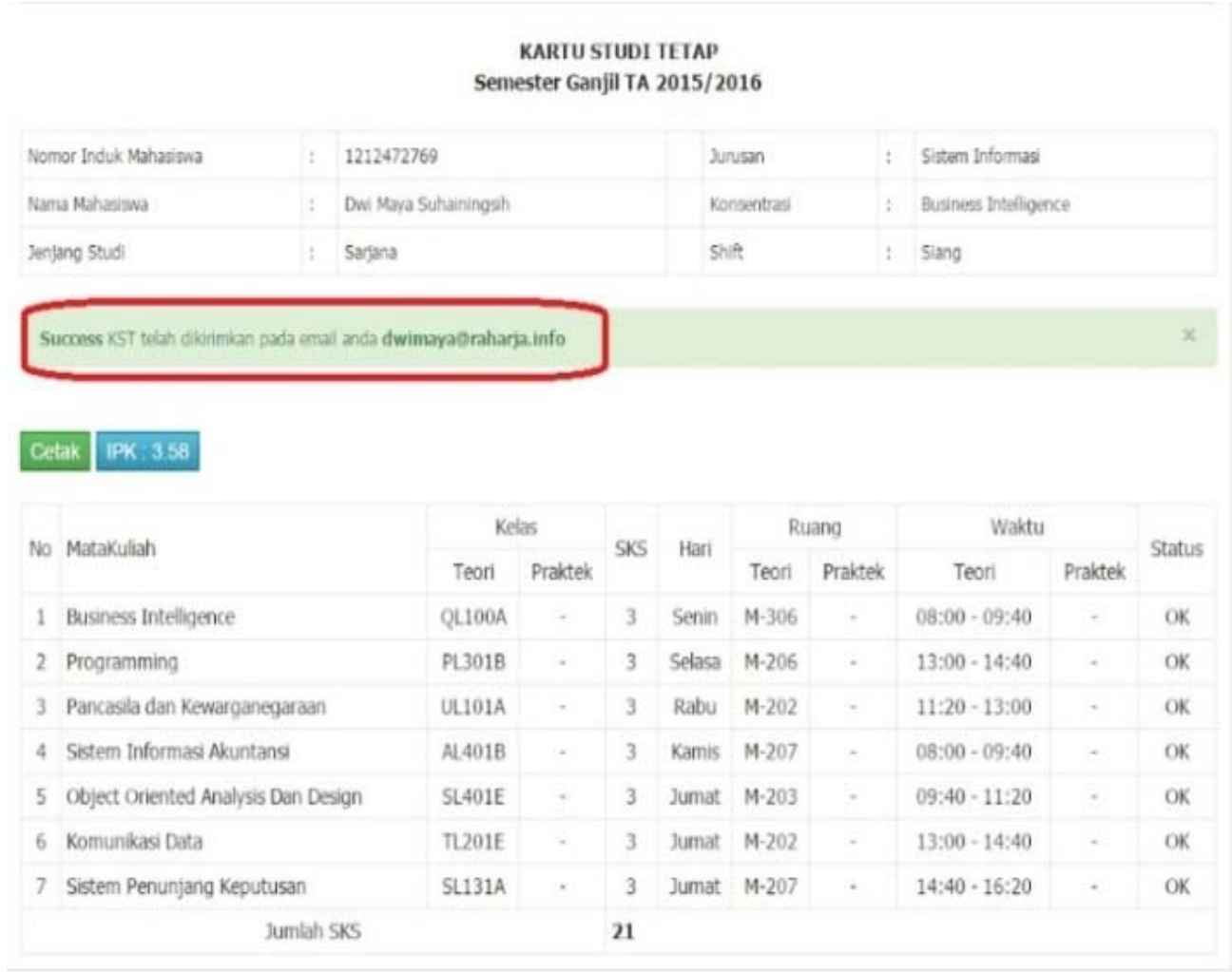

Fig.15.Form KSTF 


\section{CONCLuSION}

Based on the survey in the scheduling system and the card form study plan both students and study programs identified several problems, among others:

a) High queue; queue high, queue build up occurred during user build up resulting in high loading resulting in hangs and even system crashes.

b) Generate treatment that had been implemented should not be done added cancel process.

c) The current scheduling of 15 slots changedinto 17 slots

Generating scheduling system with Auto Generate Time Table method with Array can improve the accuracy in performing scheduling system in accordance with the planning table by the scheduling section. The scheduling results are performed using the standard constraints STMIK Raharja, while others can be implemented in other campus-tailored needs. The result of scheduling system implementation is done on the Online Jadwal Rencana Studi (OJRS) system. It is benefit to facilitate the academic administration in preparing the lecture plan at the beginning of the semester. Besides the student can do the lecture plan by filling the form of KartuRencanaStudi (KST) and Kartu Studi Tetap Final (KSTF).

\section{ACKNOWLEDGMENT}

We would like to thank DirektoratRisetdanPengabdianMasyarakat (DRPM) from KementerianRistekDikti for funding this research through the "skim hibahpenelitiandosenpemula - Hibah PDP" (practical products) program.

\section{REFERENCES}

\section{(Periodical style)}

[1] Ariani, D., Fahriza, A., \&Prasetyaningrum, I. (2011). OptimasiPenjadwalan Mata Kuliah di JurusanTeknikInformatika Pens denganMenggunakanAlgoritma Particle Swarm Optimization (PSO). EEPIS Repository, 1-11.

[2] Aziz, A. (2015). OptimasiPenjadwalanPerkuliahanMenggunakanMetode Simulated Annealing (StudiKasus: Program StudiTeknikInformatikaUniversitasYudhartaPasuruan). EXPLORE IT: JurnalKeilmuan Dan AplikasiTeknikInformatika, 7(2).

[3] Yudihartanti, Y., Syukur, A., \&Wahono, R. S. (2011). AnalisisKomparasiMetodeMamdanidanSugenodalamPenjadwalan Mata Kuliah. JurnalTeknologiInformasi, 7(2), 109-116.

[4] Siswono, T. (2013). KombinasiAlgoritmaGenetikadenganAlgoritmaPalgunadiuntukPenjadwalan Mata Kuliah di UniversitasSebelasMaret. ITSMart, 2(2), 7-12. https://doi.org/http://dx.doi.org/10.20961/its.v2i2.624.

[5] Gani, T. A. (2004). Optimizing examination timetabling using a hybrid evolution strategies Optimizing Examination Timetabling using a Hybrid Evolution Strategies. 2nd International Conference on Autonomous Robots and Agents, (June 2017), 345-349.

[6] Chu, S., \& Chen, Y. (2006). Timetable Scheduling Using Particle Swarm Optimization. IEEE Xplore, 0-3. https://doi.org/10.1109/ICICIC.2006.541.

[7] Norberciak, M. (2008). Universal Method for Timetable Construction based on Evolutionary Approach. International Journal of Social, Behavioral, Educational, Economic, Business and Industrial Engineering, 2(3), 174-179.

[8] Montero, E. (2011). A PSO algorithm to solve a Real Course + Exam Timetabling Problem. International Conference on Swarm Intelligence, 2, 1-9.

[9] Islam, T., Shahriar, Z., Perves, M.A. and Hasan, M. (2016). University Timetable Generator Using Tabu Search. Journal of Computer and Communications, 4, 28-37. https://doi.org/10.4236/jcc.2016.416003.

[10] Gunawan, C. A., \& Toba, H. (2016). PembangkitanSolusiPenjadwalanBerprioritasMelaluiPenerapan Constraint Satisfaction Problem (StudiStudiKasus: LaboratoriumFakultasTeknologiInformasiUniversitas XXX). JurnalTeknikInformatika Dan SistemInformasi, 2(April), 43-52.

[11] Putri, Y. (2014). PemanfaatanMatriksJarangdenganMetodeAlgoritmaGenetikaMenggunakan Program Pascal. JurnalMatematika UNAND, 3(1), 98-106.

[12] Satzinger John W, Jackson Robert B., \&Burd, Stephen D., (2014) System Analysis and Design in A Changing World, Couese Technology, Cengage Learning, Printed in United States of America, 60.

[13] Kumar, K., Sharma, R., \& Mehta, K. (2012). Genetic Algorithm Approach to Automate University Timetable, 1(1).

[14] Poole, L., David, Alan K., M. (2010). Artificial Intelligence: Foundations of Computational Agents. UK: Cambridge University Press. Retrieved from www.cambridge.org/9780521519007

[15] Pressman, R. S. (2010). Software Engineering: A Prectitioner's Approach. (F. M. Schilling, Ed.) (7th ed.). New York: McGraw-Hill., page: 725 .

\section{AUTHOR PROFILE}

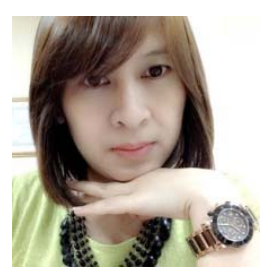

Hani DewiAriestanti., Bandung, April 18, 1978. Magister Information System in Universitas Budi Luhur, Jakarta, Indonesia. The Authors Major in Computer Science, Information System and Computer System. Secretary of Study Program in Computer Systems and Admin iDu Learning on The STMIK Raharja. Hani DewiAristanti, S.Kom., M.Kom., Professional Membership Professional Membership in AsosisasiPerguruan Tinggi IlmuKomputer - APTIKOM, and AsosiasiPerguruan Tinggi Swasta Indonesia - APTISI 

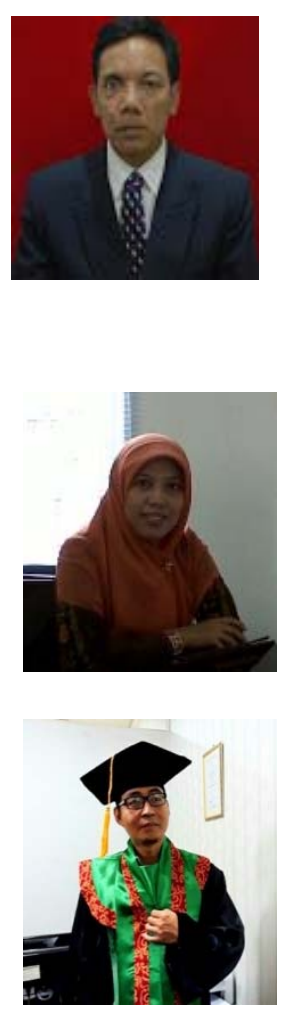

Ignatius Joko Dewanto, Jakarta, December 6, 1968. Doctoral in Educational Technology, Universitas Negeri Jakarta, Jakarta, Indonesian, 2015. The author's major of Educational Technology, Software Engineering and MIS. Assistant Head III Student Affairs and Chair of Quality Control Clusters - STMIK Raharja, Chairperson of the STKIP Setiapada Nusantara, Chair of Editor Journal of Education and Sains. Dr. Ignatius Joko Dewanto., S.Kom., MM. Professional Membership in AsosisasiPerguruan Tinggi IlmuKomputer-APTIKOM, Persatuan Guru Republik Indonesia - PGRI, and AsosiasiPerguruan Tinggi Swasta Indonesia APTISI . Reviewer on Academia.Edu and JurnalPendidikandanSains - JUPISI.

Dwi Sloria Suharti loves education world. She took English education major at State University Jakarta. Afterward, she persued studying English at Graduate School (Pascasarjana) University of Muhammadiyah Prof. Dr. Hamka Jakarta (UHAMKA). Lately, she taught English at College, Raharja College Tangerang. And Now she is a lecturer at Muhammadiyah University of Tangerang. Dwi Sloria Suharti keeps teaching as English Instructor becauses he really cares teaching, serving into her community, and researching

Muhamad Yusup, the fifth child from 9 siblings, was born in Tangerang on July 17, 1979, when he was in high school he was fond of computer science. After graduating from high school, he studied Information Systems major with a Bachelor of Computer degree at STMIK RAHARJA in Tangerang, Banten Province, Indonesia. He obtained a scholarship while working as a staff at that campus. He did not stop there, he continued to pursue his education to get Master of Computer Science at Budiluhur University, Jakarta, Indonesia. Currently, he is working as the Head of the research and community service institution at STMIK Raharja Tangerang, and also serving as Chief of the Raharja Journal Editorial Board. As a Lecturer, he is active in running the Tri Darma of Higher Education, such as lecturing Web Programming. He is also active in conducting research which is funded by government through SIMLITABMAS Ristekdikti. Besides those activities he is also active in community service in intention to build innovation villages. Presently, he is a member of the Banten Region IV-B APTISI Board and also a member of the Tangerang City LPPM Forum. 